\title{
Pinterest jako przejaw kultury obrazkowej w komunikacji marketingowej przedsiębiorstw
}

\section{Wstęp}

Współczesny marketing wymaga od przedsiębiorstwa skutecznej komunikacji ze swoimi interesariuszami. Jednym ze sposobów prowadzenia sprawnego dialogu przedsiębiorstwa $\mathrm{z}$ otoczeniem jest wykorzystanie sieci Internet. Internet i nowe media mają coraz silniejszy wpływ na procesy społeczno-gospodarcze, co wpływa na dużą zmianę profilu komunikacji. Rosnąca wciąż rola nowych mediów oddziałuje na rozwój zjawiska nazywanego marketingiem 2.0., który odnosi się do transformacji marketingu wynikającej z wpływu Internetu na działania komunikacyjne. Marketing 2.0. angażuje konsumenta i wywołuje jego reakcję zwrotną. Aktywizacja odbiorców możliwa jest w dużej mierze przez dobrze realizowane działania z zakresu internetowego public relations (sieciowego public relations; e-PRu). Dzięki temu adresat przekazu zachęcany jest do interakcji, a nawet do zainicjowania samodzielnego działania ${ }^{1}$. Obecnie coraz częściej pojawia się sformułowanie marketing 3.0., które odnosi się do tzw. technologii nowej fali, pozwalającej na łączenie się i interaktywność jednostek i grup. Klienci mogą wyrażać siebie i współpracować z innymi bez większych ograniczeń, czego szczególnym przejawem jest fala narodzin mediów społecznościowych ${ }^{2}$. $Z$ tego też powodu wydaje się, że żadna firma nie może dłużej prowadzić skutecznej komunikacji $\mathrm{z}$ otoczeniem bez wykorzystania narzędzi sieciowego public relations, ze szczególnym uwzględnieniem serwisów społecznościowych.

Współczesny Internet upraszcza komunikację. Szczególną rolę w jej procesie odgrywa coraz silniejsza ekspozycja elementów wizualnych: zdjęć, grafik (w tym coraz popularniejszych infografik), filmów, videostorytellingu. Na tej

${ }^{1}$ M. Cyran, Marketing 2.0. - zintegrowani z interaktywnymi, „Marketing w Praktyce” 2008, nr 10, s. 70-71.

${ }^{2} \mathrm{Ph}$. Kotler, H. Kartajaga, I. Setiawan, Marketing 3.0, Wyd. MT Biznes sp. z o.o., Warszawa 2010, s. $18-19$. 
podstawie rozwijają się platformy o naturze obrazkowej, których przedstawicielem jest serwis Pinterest. Jego rosnąca popularność i oryginalność, wpisująca się w rozwijającą się kulturę obrazkową, sprawiły, że jest on przedmiotem dalszych rozważań w artykule, ze szczególnym uwzględnieniem roli serwisu w komunikacji marketingowej firm.

\section{Pinterest - charakterystyka serwisu}

Pinterest przypomina wirtualną wersję tablicy korkowej, na której przypina się (od ang. pin - przypinać) zdjęcia, filmy, notki, grafiki, które spodobały się lub zainspirowały do czegoś użytkownika. Pinterest pokazał, jak prowadzić skuteczną komunikację ze współczesnym konsumentem, u którego zmienił się stosunek komunikacji tekstowej do obrazkowej. W kontekście zmiany zachowań ten sposób stał się podstawą w procesie budowania marki w sieci. Zachowana jednak została podstawowa zasada budowania marki w środowisku wirtualnym, tj. taka, że marka w Internecie „ma mieć twarz, a nie gębę”. Konsument ma ją postrzegać jak dobrego znajomego czy wręcz przyjaciela, a najlepiej gdyby ją pokochał i chciał $\mathrm{z}$ nią żyć na zawsze ${ }^{3}$.

Pinterest ma cechy wszystkich dotychczasowych portali społecznościowych, tj. dużą interaktywność, budowanie własnej społeczności, możliwość komentowania oraz lubienia. To, co go wyróżnia spośród innych, to życie społeczności, skupionej wokół serwisu, w kulturze obrazka. Jak żaden z dotychczasowych portali społecznościowych, Pinterest koncentruje się na zainteresowaniach użytkowników. Każdy z nich może pokazać swoje pasje, styl życia, ulubione postawy, rzeczy, marki, rejony świata itp. ${ }^{4}$

Zasadniczą ideą serwisu Pinterest jest połączenie ludzi poprzez rzeczy, które ich interesują. Portal umożliwia dodawanie ulubionych przedmiotów - pins w wersji wizualnej, czyli zdjęć, infografiki, wideo, które użytkownicy posiadają w swoich zasobach lub odnajdą w sieci. Ważnym elementem tego procesu jest komponowanie pinów w kolekcje (tzw. boards - tablice), które można nazywać dowolnie. Kolejną istotną cechą Pinteresta jest fakt, że wszystkie obiekty, które są na profilach użytkowników, zamieszczają linki kierujące bezpośrednio do źródła, czyli np. do konkretnej podstrony produktu w sklepie internetowym ${ }^{5}$.

${ }^{3}$ A. Ries, L. Ries, 11 praw budowania marek internetowych, IFC Press, Warszawa 2001, s. 39-49.

${ }^{4} \mathrm{http}: / /$ oxpress.pl/pinterest-nowym-narzedziem-marketingowym-e-book/.

5 D. Pacha, Pinterest jest kobieta, , ,Marketing w Praktyce” 2012, nr 5, s. 6. 
Czasami Pinterest jest również przyrównywany do pasażu w centrum handlowym, po którym spacerujemy online. Jak wcześniej wspomniano, Pinterest, podobnie jak większość serwisów społecznościowych, umożliwia lubienie i komentowanie oraz, co go wyróżnia, przepinanie obrazków w szybki sposób z tablicy na tablicę, także łatwe dzielenie się nimi w innych mediach społecznościowych. Serwis dostępny jest zarówno dla użytkowników prywatnych, jak i instytucjonalnych. Oferuje również ciekawą funkcję - metki z cenami - przypinane na zdjęciu. Funkcja ta może być szczególnie użyteczna dla profili sklepów internetowych ${ }^{6}$, stąd przyrównanie serwisu do pasażu w galerii handlowej.

Tłumacząc, czym jest Pinterest, w sposób metaforyczny można powiedzieć, że gdyby Internet miał lodówkę, to ten serwis byłby jej drzwiami, na których (tak jak w większości domów) przypina się różne informacje, wycinki, zdjęcia?

Choć często mówi się o Pintereście jako wirtualnej witrynie sklepowej, to właściwie kluczem do sukcesu jest pokazanie użytkownikom treści, z którymi się utożsamiają, niejako mogą podbić ich serca, a nie okazji zakupowych (do prezentacji których służą np. klasyczne reklamy displayowe). Do tego najlepszą i najchętniej przenoszoną jest taka, która posłuży jako element pokazania tego, kim jego odbiorca chce być bądź w jakim się pragnie pokazywać otoczeniu. Tablice zatem służą ekspresji, wyrażaniu własnej osobowości w sieci. Jeśli zatem marka nie może tego zaoferować, może zrodzić się pokusa wypełnienia luki czymś, co i tak się spodoba. Jednak podejmując takie działania trzeba liczyć się z możliwością pojawienia się problemu spójności strategii, np. stworzenie tablicy z pięknymi krajobrazami na profilu producenta opon, tablica $\mathrm{z}$ tymi samymi widokami producenta farb, gdzie pokazuje się czerpane z natury inspiracje (do zdjęć można również dodać znaczniki pantonowe farb, jako dodatkową korzyść dla odbiorcy) ${ }^{8}$.

\section{Prowadzenie profilu na Pintereście}

W odróżnieniu od Facebooka czy Twittera Pinterest nie jest platformą do autopromocji i transmitowania treści promocyjnych. Chcąc się odnaleźć w tym medium marki muszą być kreowane w odmienny sposób, zgodnie z poniższymi wskazówkami:

${ }^{6}$ T. Nadolny, Pinterestowy cud marketingowy?, „Marketing w Praktyce” 2012, nr 7, s. 10.

${ }^{7} \mathrm{http}: / /$ technologie.newsweek.pl/pinterest-com---przeczytaj-zanim-wejdziesz, $88739,1,1$. html [dostęp: 28.02.2012].

${ }^{8}$ E. Mrożek, N. Piotrowski, Przejrzeć się w Pintereście, „Marketing w Praktyce” 2012, nr 10, s. 79. 
- Opowiedzenie, jaki styl życia kryje się za marką. Na Pintereście powinno się eksponować markę, za którą stoi jakaś idea. Na portalu nie należy umieszczać klasycznych zdjęć produktów. Trzeba myśleć nieszablonowo i publikować obrazki, które są odzwierciedleniem stylu życia marki, jej esencją. Jak wcześniej wspomniano, w świecie obrazkowym głównie dąży się do tego, aby klient traktował markę jak przyjaciela, który jest częścią jego życia. W związku z tym poprzez Pinterest można ukazać kulturę firmy, zamieszczając np. zdjęcia biur, maskotek, z przerw obiadowych, wydarzeń firmowych. Fani z pewnością będą zainteresowani takimi szczegółami, a takie wyobrażenie pomoże „uczłowieczyć” markę.

- Zarządzanie szerokim zakresem tablic luźno powiązanych z produktami. Firma ma możliwość umieszczenia na portalu nieograniczonej liczby tablic, dzięki temu użytkownicy mogą zainteresować się jedną wybraną, kilkoma lub wszystkimi. Zarządzanie szeroką paletą tablic w różnych kategoriach pozwala większej liczbie zróżnicowanych użytkowników poznać firmę. Dla przykładu firma Rent the Runway, specjalizująca się w wypożyczaniu strojów na różne okazje (wesela, bankiety i inne), pogrupowała swoje tablice według okazji: wieczór kawalerski, jesienny ślub, impreza taneczna, sylwester itp. Takie pogrupowanie ma na celu pomoc w wyborze odpowiednich strojów na poszczególne okazje.

- Analizowanie zachowań użytkowników. Użytkownicy serwisu najczęściej śledzą przedmioty, które lubią, miejsca, które odwiedzają (lub chcieliby odwiedzić), jedzenie, które zazwyczaj spożywają oraz rzeczy, które ich inspirują. Dlatego można je traktować jak swoiste grupy fokusowe. Jeżeli jakaś grupa użytkowników Pinteresta interesuje się marką, daje to podstawę do prowadzenia analizy tego, co przyczepiają na tablicę i kogo jeszcze śledzą. W ten sposób użytkownicy przekazują wiele informacji o sobie, które z kolei pozwalają na zgłębienie wiedzy na temat własnej grupy docelowej.

- Zezwolenie konsumentom na umieszczanie własnych informacji - przypięcia zdjęć, na których pozują z ulubionym produktem firmy. Takie działanie pokaże potencjalnym klientom, że ci obecni naprawdę lubią i są zadowoleni z produktów firmy.

- Organizowanie konkursów, pozwala przyciągnąć uwagę i zatrzymać użytkownika. Konkurs może polegać np. na opracowaniu tablicy „Pin It To Win It”. Na takiej zasadzie konkurs zorganizowała firma odzieżowa Land's End Canvas. W ramach kampanii użytkownicy mieli tworzyć tablice w kategorii męskie lub damskie ubranie i przypiąć do każdej od 10 do 20 zdjęć ze strony Land's End lub profilu firmy na Pintereście.

- Pokazanie, co inspiruje markę. Opracowując tablicę inspiracji dla własnej firmy/marki i przyczepiając rzeczy, które są ważne, inspirujące, interesujące firmę 
lub jej pracowników, należy zamieszczać logo i dobrze zaprojektowane strony, przemyślane hasła reklamowe. Trzeba pamiętać, że obraz jest tutaj najważniejszy.

- Używanie oryginalnych zdjęć, własnoręcznie wykonanych i oryginalnych obrazków wywoła większe zainteresowanie nimi, co powinno wygenerować większy ruch wokół profilu firmy.

- Opracowanie katalogów - stworzenie pinboardu i przyczepianie obrazków opartych na jednej z kolekcji firmy lub linii produktowej. Takie działanie przyciąga do profilu firmowego użytkowników zainteresowanych kupnem przyczepionego produktu?.

Skorzystanie z powyższych wskazówek pomoże w odpowiedni sposób kreować markę w serwisie. Jednak równie istotna będzie efektywność samego profilu. Ta może być większa, jeżeli będą przestrzegane kolejne porady:

- Korzystanie z wyszukiwarki w celu zbudowania bazy treści wewnątrz serwisu. Pinterest daje możliwość wyszukiwania konkretnych grafik, tablic i osób. Do tego należy zastanowić się, jakie słowa kluczowe odpowiadają temu, co firma będzie publikować w serwisie. W nawiązaniu do tego warto dodać do obserwowanych odpowiednie pod względem treści tablice. Tablice danego konta warto dodawać tylko wówczas, gdy pokrywają się one z zapotrzebowaniami firmy. Przenosząc do swoich tablic dane, które mogą zainteresować grupę docelową firmy, ta zaznacza swoją obecność w serwisie - powiadomienia mailowe pojawią się u osób, których tablice dodano do obserwowanych, lub których dane zostały przekazane dalej. Dodatkowym sposobem na gromadzenie grafik (lub filmów), których z jakiś powodów firma nie chce przenosić, jest polubienie ich (w ten sposób również można zwrócić na siebie uwagę).

- Używanie tagów i słów kluczowych. Aby zostać w serwisie odnalezionym należy używać słów kluczowych zarówno w opisach pinów, jak i w nazwach i opisach tablic oraz w opisie samego konta.

- Połączenie konta na Pintereście z innymi serwisami społecznościowymi Twitterem i Facebookiem ${ }^{10}$.

Każdego dnia około 300 mln zdjęć jest załączanych do kont na Facebooku. Przybliżona liczba zdjęć i obrazków opublikowanych w nim ogółem to ponad 200 mld. Na przełomie 2012 i 2013 roku w ciągu 48 godzin użytkownicy Facebooka dodali 1,1 mld zdjęć, głównie pokazując jak świętowano Nowy Rok ${ }^{11}$. W trend

${ }^{9}$ W. Krawiec, Pinterest - portal nowych możliwości dla budowania marki oraz lojalności klienta, „Zeszyty Naukowe Uniwersytetu Szczecińskiego” 2013, Ekonomiczne Problemy Usług nr 105 , s. 335-337.

${ }^{10} \mathrm{http}: / /$ nowymarketing.pl/a/346,jak-prowadzic-profil-na-pinterescie-case-study-muzeumerotyzmu [dostęp: 15.06.2013].

${ }^{11}$ B. Frątczak-Rudnicka, Marketing w obrazkowym świecie, „Marketing w Praktyce” 2013, nr 6, s. 6 . 
obrazkowy, którego większość mediów społecznościowych jest uczestnikiem, Pinterest wpisuje się idealnie, ponieważ obraz i jego przekaz jest głównym elementem komunikacji.

Najliczniejszą grupę ludzi stanowią wzrokowcy, co ma szczególne znaczenie dla prowadzonych działań komunikacyjnych przedsiębiorstw. Obecna kultura piktograficzna sprawiła, że chłoniemy otaczającą nas rzeczywistość podawaną za pomocą obrazów ${ }^{12}$.

Dlatego o fenomenie Pinteresta można mówić w kontekście coraz popularniejszego hasła kultury obrazkowej, odnoszącego się do zjawiska zaznaczającego coraz silniej swoją obecność zarówno w świecie wirtualnym, jak i rzeczywistym. Pinterest może okazać się kanałem wpisującym się właśnie w ten trend, gdy ludzie czytają coraz mniej. Powstaje pytanie jak opowiedzieć o marce obrazami? Dobrym przykładem takiej opowieści jest The Body Shop, który wykorzystał tablice do zamieszczania zdjęć oraz coraz popularniejszych infografik na temat działalności na rzecz ochrony środowiska, obrony praw człowieka oraz wzmocnienia poczucia własnej wartości, pokazując w ten sposób misję i charakter marki przy jednoczesnym utrwaleniu jej USP (unique selling proposition) ${ }^{13}$.

Samo bycie w serwisie Pinterest nie wystarczy, dlatego warto wykorzystać dostępne dodatki. Po pierwsze wspomnianą już wtyczkę pin it, spotykaną coraz częściej w polskich sklepach internetowych i blogach, rzadziej w serwisach WWW firm. Dla przykładu w przypadku dodania wtyczki do bloga kulinarnego każde kliknięcie zdjęcia na e-tablicy podnosi pozycjonowanie bloga. Dzięki Pinterestowi, pomimo obecności w sieci setek przepisów na ciasto drożdżowe, przepis z bloga może znaleźć się na pierwszej stronie wyszukiwarki (więc można go traktować jako element działań z zakresu SEO). Drugim dodatkiem jest prawie nieobecny w polskiej sieci follow me buton, który pozwala na pozyskanie śledzących z zewnątrz w inny sposób niż jedynie przez crown-sourcing z Facebooka ${ }^{14}$.

Istnieje często powielany pogląd, że do skutecznych działań w Pintereście potrzebny jest niestandardowy pomysł. Jednak doświadczenia wielu firm pokazują, że wcale nie oryginalny pomysł, a jakość zdjęć oraz systematyczność wprowadzania nowych danych jest najważniejsza ${ }^{15}$.

Raport opracowany przez Bizrate Insights podkreśla szczególną cechę serwisu - prosprzedażową. Wyniki badań wskazują, że 70\% użytkowników odwiedza Pinteresta w celu znalezienia inspiracji zakupowej i prawie tyle samo (69\%)

\footnotetext{
${ }^{12}$ M. Kniaź, Narkomani obrazów, „Marketing w Praktyce” 2013, nr 5, s. 34.

13 E. Mrożek, N. Piotrowski, op. cit., s. 78.

${ }^{14}$ Ibidem.

15 T. Nadolny, op. cit., s. 11.
} 
znalazło tam rzecz, którą później kupiło lub zamierzało kupić. Dla porównania na Facebooku wyniki te kształtowały się odpowiednio 40 i 17\%. Możliwe, że jest to spowodowane możliwością dodawania ceny do produktów przedstawianych na fotografiach ${ }^{16}$. Ciekawe są dane dotyczące aktywności samych użytkowników. Badanie, przeprowadzone na przełomie stycznia i lutego 2012 roku przez RJ Metrics, wykazało, że $80 \%$ zamieszczanej treści pochodzi z przenoszenia wewnątrz serwisu, co pokazuje jego ogromny potencjał wirusowy ${ }^{17}$.

Nawiązując do tego potencjału warto zauważyć, że tym, co odróżnia Pinterest od innych serwisów społecznościowych wykorzystywanych przez firmy w komunikacji marketingowej, jest źródło wpływu na konsumentów. Komunikacja związana z markami czy produktami na NK bądź Facebooku w większości przypadków jest inicjowana przez same firmy. W serwisach tych użytkownicy spędzają czas głównie w celach prywatnych i rozrywkowych. Jeśli włączają się w dyskusje związane z produktami, robią to najczęściej pod wpływem przekazów ze strony firm. Zatem pod względem marketingowym Facebook i NK to narzędzia B2C. Nawet jeżeli użytkownicy sami poruszają tematy związane z produktami, robią to najczęściej w otoczeniu znajomych. Treści publikowane w Pintereście to w dużej mierze konkretne produkty. Decyzja o ich popularności w serwisie w sposób nieznaczny zależy od przedsiębiorstw. Fakt ten sprawia, że Pinterest jest w istotnie większym stopniu platformą C2C, choć zyskują na znaczeniu konta firmowe, które bardziej wpisują się w ton komunikacji $\mathrm{B} 2 \mathrm{C}^{18}$. Konto firmowe na Pintereście jest dostępne nie tylko dla podmiotów gospodarczych, ale m.in. również dla fotografów, blogerów, designerów, sportowców, muzyków, polityków czy aktorów. Do wyboru są następujące kategorie kont: Professional, Public Figure, Media, Brand, Retailer, Online Marketplace, Local Business oraz Institution Non-profit ${ }^{19}$.

W Polsce Pinterest jest nadal kanałem mało wykorzystywanym przez marki, co może być spowodowane stosunkowo małą liczbą użytkowników. Według danych Megapanel PBI/Gemius w styczniu 2013 roku Pinterest odwiedziło 443580 real users, w lutym 514 121, a w marcu $456351^{20}$. Niewiele jest takich marek, którym udało się uzyskać większą liczbę „,polubień” lub komentarz do zdjęcia. Firmy mają problem z zaangażowaniem swoich śledzących. W tym zakresie dobrym przykładem jest marka Reserved, która gromadzi relatywnie dużo fanów w każdym z wykorzystywanych kanałów social media (na portalu Pinterest ponad 500,

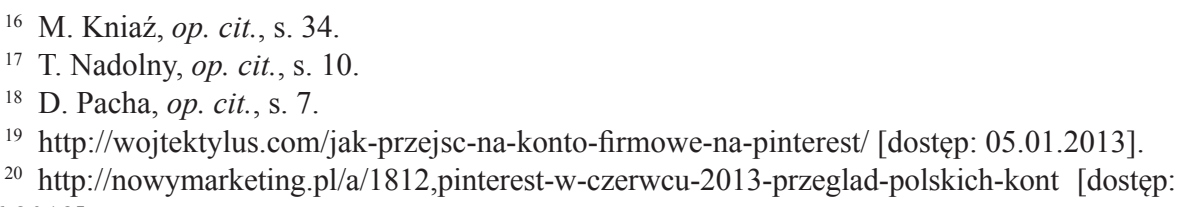


co jest aktualnie dobrym wynikiem, w porównaniu z innymi polskimi brandami), natomiast nie są oni skorzy do angażowania się w życie marki. Jest to o tyle interesujące, że profil Reserved na Pintereście promowany jest również poprzez stronę na Facebooku, która w branży odzieżowej zajmuje w Polsce pierwsze miejsce pod względem liczby fanów. Poza tym branża ta należy do tych, wśród których dobre zdjęcia są gwarantem sukcesu na rynku, a tych Reserved ma wiele - świadczy o tym także ponad 2000 pinów marki ${ }^{21}$. Jednak liczby te nie powinny zniechęcać do aktywności w Pintereście. Wręcz przeciwnie. Warto przyjrzeć się ciekawym kampaniom ze świata i być może czerpać z nich inspiracje do własnych działań.

Ciekawym debiutem na Pintereście była kampania Gucci. Marka po uruchomieniu profilu w portalu zdecydowała się na kampanię banerową m.in. na WSJ. com („The Wall Street Journal”), Polyvore, Style.com, Lifestyle Mirror oraz na blogu modowym New York Magazine - The Cut. Owe banery oznaczone były butonem „Pin it”, po kliknięciu którego użytkownik otrzymywał na Pintereście dwa zdjęcia: wizerunkowe i produktowe (packshot) butów Gucci, które z kolei opatrzone były linkiem do sklepu internetowego marki ${ }^{22}$. W innym przypadku amerykański odział sieci perfumerii Sephora zintegrował w pełni swój sklep internetowy z Pinterestem. Dzięki temu klienci tej marki i jednocześnie użytkownicy portalu mogą w łatwy sposób dzielić się swoimi inspiracjami na tablicy ${ }^{23}$.

Jak już wspomniano, patrząc na obecne statystyki popularności Pinteresta można się zastanawiać, czy warto rozwijać na nim obecność swojej firmy. Jednak wydaje się, że w planach strategii komunikacji z otoczeniem należy uwzględnić ten serwis z kilku przyczyn:

- Szacunki rozwoju Pinteresta są optymistyczne. Szacuje się, że obecnie serwis ma 20-40 milionów unikalnych użytkowników miesięcznie na całym świecie i liczba ta stale się powiększa.

- Grupę docelową stanowią kobiety. Według różnych źródeł panie w wieku 18-44 lata stanowią od 60 do 80 procent użytkowników. Swoistą męską odpowiedzią na „sfeminizowanego" Pinteresta ma być Dart It Up (dartitup.com). Czas jednak pokaże, czy ten startup przyjmie się na rynku.

- Jakościowe dobranie użytkowników poprzez personalizację. Przy rejestracji użytkownicy wybierają interesujące ich kategorie tematów, które pozwalają na budowanie jakościowego zasięgu oraz szukania wpływowych użytkowników portalu - kuratorów treści (content curation).

- Wzmocnienie działań SEO (search engine optimization). Google przy pozycjonowaniu preferuje unikalne treści, a w szczególności materiały wizualne.

${ }^{21}$ M. Kniaź, op. cit., s. 35.

${ }^{22}$ Ibidem.

${ }^{23} \mathrm{http}: / /$ socjomania.pl/pinterest-w-polsce-warto-sie-nim-zainteresowac-bo/ [dostęp: 18.05.2012]. 
- Czas spędzany przez użytkowników w serwisie wynosi około 90 minut miesięcznie i ustępuje tylko Facebookowi. Polski użytkownik Pinteresta spędza w serwisie niespełna 10 minut.

- Spersonalizowane możliwości sprzedażowe dzięki działowi „Gifts”. Użytkownicy rekomendują rzeczy, które warto kupić. To dobre miejsce na znalezienie fanów zakupów oraz poinformowanie ich o istnieniu konkretnych produktów czy marki.

- Możliwość wielopoziomowej interakcji i przeprowadzenia wizualnych projektów (w tym konkursów) wciągających konsumentów ${ }^{24}$.

\section{Zakończenie}

Pinterest przyczynił się do pokazania świata marki przez pryzmat kultury obrazkowej. Za pomocą elementów wizualnych inspiruje użytkowników, oddziałuje na ich emocje, sprawia że marki utrwalają się w umysłach konsumentów, a także wspierają procesy podejmowania decyzji zakupowych. W przypadku działań prowadzonych przez firmy istotny jest sam pomysł na kampanię w serwisie. Liczą się przede wszystkim działania nieszablonowe, kreatywne, przy wsparciu odpowiedniego kontentu - angażującego i dedykowanego dla tego medium ${ }^{25}$. Choć wykorzystanie Pinterestu w Polsce nie jest duże, wyraźnie widać coraz większe nim zainteresowanie za sprawą m.in. udanych kampanii z jego użyciem na świecie oraz wciąż rosnącej liczby użytkowników.

\section{Bibliografia}

Buczny E., Reguly kontentu w sieci, „Marketing w Praktyce” 2012, nr 12 Cyran M., Marketing 2.0. - zintegrowani z interaktywnymi, „Marketing w Praktyce" 2008, nr 10

Frątczak-Rudnicka B., Marketing w obrazkowym świecie, „Marketing w Praktyce” 2013, nr 6

Kniaź M., Narkomani obrazów, „Marketing w Praktyce” 2013, nr 5

Kotler Ph., Kartajaga H., Setiawan I., Marketing 3.0, Wyd. MT Biznes sp. z o.o., Warszawa 2010

${ }^{24} \mathrm{http}: / /$ socjomania.pl/pinterest-w-polsce-warto-sie-nim-zainteresowac-bo [dostęp: 18.05.2012]; http://nowymarketing.pl/a/28,pinterest-czy-polskie-marki-maja-tu-czego-szukac [dostęp: 14.06.2012].

${ }^{25}$ E. Buczny, Reguly kontentu w sieci, „Marketing w Praktyce” 2012, nr 12, s. 23. 
Krawiec W., Pinterest - portal nowych możliwości dla budowania marki oraz lojalności klienta, „Zeszyty Naukowe Uniwersytetu Szczecińskiego” 2013, Ekonomiczne Problemy Usług, nr 105

Mrożek E., Piotrowski N., Przejrzeć się w Pintereście, „Marketing w Praktyce” 2012, nr 10

Nadolny T., Pinterestowy cud marketingowy?, „Marketing w Praktyce” 2012, nr 7

Pacha D., Pinterest jest kobieta, „Marketing w Praktyce” 2012, nr 5

Ries A., Ries L., 11 praw budowania marek internetowych, IFC Press, Warszawa 2001

http://www.nowymarketing.pl

http://www.oxpress.pl

http://www.socjomania.pl

http://www.technologie.newsweek.pl

http://www.wojtektylus.com 